\title{
Implementasi Hukum Islam \\ dan Pengaruhnya Terhadap Politik Hukum Indonesia
}

\section{The Implementation of Islamic Law and Its Influence on Indonesian Legal Politics}

\author{
Ahmad Suganda \\ Sekolah Tinggi Agama Islam (STAI) Syamsul 'Ulum Gunungpuyuh \\ Sukabumi, Jawa Barat, Indonesia \\ ahmadsuganda61@gmail.com
}

\begin{abstract}
Abstrak
Kajian implementasi hukum Islam dan pengaruhnya terhadap hukum di Indonesia dapat dijadikan sebagai acuan dalam strategi harmonisasi antara hukum Islam dan hukum positif. Tujuan penelitian adalah mendeskripsikan pengimplementasian hukum Islam dan menganalisis pengaruhnya terhadap hukum di Indonesia. Penelitian menggunakan pendekatan kualitatif dengan metode deskriptif. Data didapatkan dari beberapa sumber literatur terpercaya yang memperkuat hasil anaslisis. Adapun teknik analisis yang digunakan adalah analisis induktif. Hasil penelitian menunjukan bahwa implementasi hukum Islam di Indonesia menyesuaikan dengan sistem hukum yang berlaku yang berlandaskan kepada ideologi dan konstitusional negara yaitu UUD 1945 dan Pancasila. Dari hasil penelitian dapat disimpulkan bahwa hukum Islam memiliki peluang besar untuk diimplementasikan terhadap politik hukum di Indonesia secara gradual sehingga terpolarisasi dalam pembentukan sistem hukum yang berlaku di Indonesia.
\end{abstract}

Kata kunci: Hukum Islam, Politik Hukum dan Sistem Hukum yang Berlaku

\section{Abstract}

The research of implementation of Islamic law and it's influence on law in Indonesia can be use as a reference in the harmonization strategy between Islamic law and positive law. This research aims to describe the implementation of Islamic law and analyze it's influence on law in Indonesia. This research used a qualitative approach with descriptive method. Data obtained from reliable literature sources which confirmed the results of analysis. The analysis technique used inductive analysis. The research found that the implementation of Islamic law in Indonesia adjusts to the prevailing legal system based on the state ideology and constitution namely the 1945 Constitution and Pancasila. Based on the result of reseach can be concluded that Islamic law has a great opportunity to implement in the politics of law in Indonesia gradually so it is polarized in the formation of the legal system in Indonesia.

Keywords: Islamic Law, Political Law and the Applicable Legal System 


\section{PENDAHULUAN}

Umat Islam Indonesia dalam kancah dunia internasional, dapat dikatakan sebagai komunitas muslim paling besar yang berada dalam satu batas teritorial kenegaraan yang sangat diperhitungkan keberadaannya. Oleh karena itu, menjadi sangat menarik untuk menganalis implementasi dan pengaruh perkembangan sejarah hukum Islam di tengah-tengah komunitas Islam terhadap penerapan hukum Islam di tanah air mulai sejak komunitas muslim hadir di Indonesia. Kajian tentang implementasi dan pengaruh hukum Islam di Indonesia dapat dijadikan sebagai salah satu pijakan bagi umat Islam secara khusus untuk menentukan strategi yang tepat di masa depan dalam mendekatkan dan "mengakrabkan" bangsa ini dengan hukum Islam.
Proses sejarah hukum Islam yang diwarnai "benturan" dengan tradisi yang sebelumnya berlaku dan dengan kebijakan-kebijakan politik kenegaraan, serta tindakantindakan yang diambil oleh para tokoh Islam Indonesia terdahulu, dapat menjadi bahan telaah penting di masa yang akan datang. Pengaruh itu menunjukkan bahwa proses islamisasi sebuah upaya yang sungguh-sungguh secara bertahap (tadarruj), sehingga norma-norma syari'at Islam dapat mewarnai perundang-undangan di Indonesia, karena hukum Islam merupakan salah satu dasar pembentukan hukum positif.

Adapun yang dimaksud dengan hukum Islam adalah "upaya fuqaha dalam menerapkan syari'at Islam sesuai kebutuhan masyarakat" (Ash-Shiddiqy, 1993). Sedangkan Politik Hukum Islam adalah "perluasan peran 
penguasa untuk merealisasikan kemaslahatan manusia sepanjang hal-hal tersebut tidak bertentangan dengan dasar-dasar agama" (Khallaf, 2005). Dengan demikian dapat dikatakan bahwa politik hukum Islam merupakan pilihan tentang hukum-hukum yang akan diberlakukan dan sekaligus pilihan tentang hukum-hukum yang akan dicabut atau tidak diberlakukan yang kesemuanya ini dimaksudkan untuk mencapai tujuan negara seperti yang tercantum dalam pembukaan UUD 1945 (Mahfud MD, 2010).

Menurut Isjwara (1964) "politik" mengandung beberapa pengertian di antaranya: (a) Apa yang berhubungan dengan pemerintahan; (b) Perkara mengelola, mengarahkan dan menyelenggarakan kebijaksanaan umum dan keputusan-keputusan atau kebijaksanaan yang menyangkut partai-partai yang berperan dalam kehidupan bernegara; (c). Bidang studi yang berkaitan dengan masalah-masalah sipil-sosial dan mengembangkan pendekatan-pendekatan terhadap pemecahan masalah-masalah tersebut; (d) Aktivitas yang berkaitan dengan relasi-relasi antara bangsa-bangsa dan kelompok-kelompok social lainnya, yang berhubungan dengan perkara penggunaan kekuasaan negara. Berikutnya Wahyono (1986) mengemukakan bahwa kebijakan dasar yang menentukan, arah, bentuk maupun isi hukum yang akan dibentuk, dijelaskan lebih lanjut bahwa politik hukum adalah kebijakan penyelenggara negara tentang apa yang dijadikan kriteria untuk menghukumkan sesuatu yang di dalamnya mencakup perumusan, pembentukan, penetapan dan penegakan hukum.

Dari beberapa pengertian tersebut dapat disimpulkan bahwa yang dimaksud dengan politik hukum Indonesia disini adalah kebijakan dasar penyelenggara 
negara (Republik Indonesia) dalam bidang hukum yang akan, sedang dan telah berlaku yang bersumber dari nilai-nilai yang berlaku dalam masyarakat untuk mencapai tujuan negara yang dicita-citakan. Dalam pengertian ini ada 5 (lima) hal yang dititikberatkan sebagai agenda dalam politik hukum Indonesia yaitu,(1) Tujuan politik hukum nasional, (2) Kebijakan dasar yang meliputi konsep dan letak, (3) Penyelenggara negara sebagai pembentuk konsep dasar tersebut, (4) Materi hukum yang meliputi hukum yang akan, sedang dan telah berlaku serta, (5) Proses pembentukan hukum.

Jadi dalam politik hukum Indonesia kelima unsur di atas merupakan agenda yang dijadikan pedoman dasar bagi segala bentuk dan proses perumusan, pembentukan dan pengembangan hukum di tanah air yang dirumuskan dalam peraturan perundang-undangan yang bersifat mendasar. Sehubungan dengan hal tersebut, penulis menyoroti tujuan politik hukum Islam dan kebijakan dasar tentang konsep dan letak politik hukum nasional yang diwarnai oleh norma-norma syari'at Islam.

\section{METODE PENELITIAN}

Di dalam penelitian ini, penulis menggunakan metode deskriptif analisis yaitu metode yang memberikan gambaran umum dan analisis tentang implementasi hukum Islam dan pengaruhnya terhadap pembentukan hukum nasional. penelitian ini menggunakan teori kedaulatan Tuhan yaitu teori syahadat, atau teori kredo ialah teori yang mengharuskan pelaksaan hukum Islam oleh mereka yang telah mengucapkaan dua kalimat syahadat sebagai konsekwensi logis dari pengucapan kredonya (Cahyadi \& Manullang, 2007). Data didapatkan dari beberapa sumber literature terpercaya, sehingga memperkuat hasil anaslisis. Adapun teknik analisis 
yang digunakan adalah analisis induktif yaitu pencarian hasil penelitian yang didasarkan pada data-data yang diperoleh, sehingga pada akhirnya dapat ditarik kesimpulan menjadi hasil penelitian dalam bentuk teori, konsep dan sebagainya.

\section{HASIL}

DAN

PEMBAHASAN

\section{A. Perkembangan Hukum Islam}

\section{di Indonesia}

Perkembangan Hukum Islam di Indonesia mengalami beberapa fase, yaitu:

a. Islam di Masa Pra Penjajahan Belanda

Menurut sebagian ahli sejarah awal mulai masuknya Islam di Nusantara pada abad pertama hijriyah, atau pada sekitar abad ketujuh dan kedelapan masehi, dan sebagai gerbang masuknya, adalah melalui kawasan utara Pulau Sumatera yang kemudian dijadikan sebagai titik awal gerakan dakwah para pendatang muslim. Secara bertahap gerakan dakwah mulai membentuk masyarakat Islam pertama di Peureulak, Aceh Timur, dan berkembang ke beberapa daerah lainnya di sekitar wilayah tersebut kemudian diikuti dengan berdirinya kerajaan Islam pertama di tanah air pada abad 13, yang dikenal dengan nama Kerajaan Samudera Pasai yang terletak di wilayah Aceh Utara (Ali, 2013).

Pengaruh Islam yang begitu cepat menyebar hingga ke berbagai wilayah nusantara yang menyebabkan beberapa kerajaan Islam berdiri menyusul berdirinya Kerajaan Samudera Pasai di Aceh, tidak jauh dari Aceh berdiri Kesultanan Malaka, lalu di Pulau Jawa berdiri Kesultanan Demak, Mataram dan Cirebon, kemudian berkembang ke bagian timur Nusantara seperti di Sulawesi dan Maluku berdiri Kerajaan Gowa dan Kesultanan Ternate dan Tidore.

Kesultanan tercatat dalam sejarah ini mulai menetapkan hukum Islam sebagai hukum positif yang berlaku, dengan penetapan 
hukum Islam sebagai hukum positif di setiap kesultanan tersebut, maka sudah tentu akan memperkuat pengamalannya tentang hukum dan syariat Islam yang memang telah berkembang di masyarakat muslim masa itu. Fakta-fakta ini dibuktikan dengan adanya literatur-literatur fiqh yang ditulis oleh para ulama nusantara pada sekitar abad 16 dan 17. Kondisi ini terus berlangsung hingga para pedagang Belanda datang ke kawasan nusantara.

2. Hukum Islam Masa Penjajahan Belanda

Pemberlakuan hukum Islam oleh Pemerintah Hindia Belanda dapat disimpulkan, secara kronologis sebagai berikut:

a. Pada pertengahan abad 19, Pemerintah Hindia Belanda melaksanakan Politik Hukum yang sadar, yaitu kebijakan yang secara sadar ingin menata kembali dan mengubah kehidupan hukum di Indonesia dengan hukum Belanda. b. Atas dasar nota yang disampaikan oleh Mr. Scholten Van Oud Haarlem, Pemerintah Belanda menginstruksikan penggunaan undang-undang agama, lembaga-lembaga dan kebiasaan pribumi dalam hal persengketaan yang terjadi di antara mereka, selama tidak bertentangan dengan asas kepatutan dan keadilan yang diakui umum. Klausul terakhir ini kemudian menempatkan hukum Islam di bawah subordinasi dari hukum Belanda.

c. Atas dasar teori receptie yang dikeluarkan oleh Snouck Hurgronje, Pemerintah Hindia Belanda pada tahun 1922 kemudian membentuk komisi untuk meninjau ulang wewenang pengadilan agama di Jawa dalam memeriksa kasuskasus kewarisan (dengan alasan, ia belum diterima oleh hukum adat setempat). 
d. Pada tahun 1925, dilakukan perubahan terhadap Pasal 134 ayat 2 Indische Staatsregeling (yang isinya sama dengan Pasal 78 Regerringsreglement), yang intinya perkara perdata sesama muslim akan diselesaikan dengan hakim agama Islam jika hal itu telah diterima oleh hukum adat dan selama tidak ditentukan lain oleh sesuatu ordonasi (Ali, 2013).

Lemahnya posisi hukum Islam ini terus terjadi hingga menjelang berakhirnya kekuasaan Hindia Belanda di wilayah Indonesia pada tahun 1942.

3. Hukum Islam Masa Pendudukan Jepang

Pemerintah Pendudukan Jepang tetap melakukan berbagai kebijakan untuk menarik simpati umat Islam di Indonesia, di antaranya adalah:

a. Panglima Militer Jepang berjanji untuk melindungi dan memajukan Islam sebagai agama mayoritas penduduk pulau Jawa.

b. Mendirikan Shumubu (Kantor Urusan Agama Islam) yang dipimpin oleh bangsa Indonesia sendiri.

c. Mengizinkan berdirinya ormas Islam, seperti Muhammadiyah dan NU.

d. Menyetujui berdirinya Majelis Syura Muslimin Indonesia (Masyumi) pada bulan Oktober 1943. Yang pada akhirnya saat itu menjadi Partai Politik.

e. Menyetujui berdirinya Hizbullah sebagai pasukan cadangan yang mendampingi berdirinya tentara PETA (Pembela Tanah Air) (Wibawa, 2001).

f. Berupaya memenuhi desakan para tokoh Islam untuk mengembalikan kewenangan Pengadilan Agama dengan meminta seorang ahli hukum adat, Soepomo, pada bulan Januari 1944 untuk menyampaikan laporan tentang 
hal itu. Namun upaya ini kemudian "dimentahkan" oleh Soepomo dengan alasan kompleksitas dan menundanya hingga Indonesia merdeka (Ali, 2013).

Atas situasi pada saat yang demikian, nyaris tidak ada perubahan berarti bagi posisi hukum Islam selama masa pendudukan Jepang di tanah air. Namun bagaimanapun juga, masa pendudukan Jepang masih lebih baik dari pada Hindia Belanda terutama dari sisi adanya pengalaman baru bagi para pemimpin Islam dalam mengatur masalah-masalah keagamaan. Abikusno Tjokrosujoso menyatakan bahwa, kebijakan pemerintah Belanda telah memperlemah posisi Islam. Islam tidak memiliki para pegawai di bidang agama yang terlatih di masjid-masjid atau pengadilanpengadilan Islam. Belanda menjalankan kebijakan politik yang memperlemah posisi Islam.
Ketika pasukan Jepang datang, mereka menyadari bahwa Islam adalah suatu kekuatan di Indonesia yang dapat dimanfaatkan.

4. Era Demokrasi Parlementer (1945-1959) dan Politik Hukum Indonesia

Di dalam membangun sistem hukum nasional pemerintah telah menetapkan kebijakan untuk memanfaatkan tiga sistem hukum yang hidup eksis (living law) dan berkembang di Indonesia sebagai bahan bakunya yaitu, (1) Hukum Adat, (2) Hukum Islam dan (3) Hukum Barat (Belanda), dalam masa colonial ketiga sistem hukum ini mulai berlaku di Indonesia pada waktu yang berlainan. Hukum adat sudah lama ada dan berlaku di Indonesia walaupun baru dikenal sebagai sistem hukum pada abad ke-20. Hukum Islam telah ada di Kepulauan Indonesia sejak orang Islam datang dan bermukim di Nusantara sejak abad pertama Hijriah atau pada abad ketujuh/ kedelapan. Pendapat lain 
mengemukakan Islam datang di Nusantara pada abad ke-13 (Ali, 2013). Daerah yang pertama didatangi adalah pesisir Utara Sumatera dengan membentuk masyarakat Islam pertama di Peureulak Aceh Utara dan Samudra Pasai. Kemudian Hukum Barat mulai diperkenalkan sejak datangnya VOC. Tahun 1602 mulamula diberlakukan terhadap orangorang Belanda dan Eropa saja tetapi dengan berbagai peraturan dan upaya dinyatakan berlaku bagi orang-orang Asia dan termasuk penduduk pribumi di Nusantara.

Menurut Analisis Bustanul Arifin walaupun Hindia Belanda telah hengkang dari bumi Nusantara tetap saja suasana ketiga sistem hukum ini konflik, karena masih ada para ahli hukum mempertentangkan ketiganya dan mengunggulkan salah satu dari yang lain. Hal ini tentu tidak baik bagi proses pembangunan sistem hukum nasional yang dicitacitakan. Disamping itu pula perspektif epistemologi kita belum memiliki apa yang disebut sebagai "Ilmu hukum nasional" atau "teorisasi hukum Indonesia" (Rahardjo, 1988), padahal kita sangat memerlukannya sebagai dasar untuk merumuskan sistem hukum nasional yang sesuai dengan karakteristik bangsa Indonesia karena tidak mungkin selamanya kita menggunakan teoriteori hukum dari Barat. Dari penjelasan ini ternyata kita belum memiliki sistem hukum nasional yang representatif. Namun bukan berarti idealitas tentang sistem hukum nasional yang dikehendaki tidak diupayakan, pihak pemerintah dan kampus telah mengadakan beberapa pertemuan ilmiah dan seminar berskala nasional dan lokal yang dihadiri oleh para ahli hukum

Dalam hal ini untuk mendukung kehendak bangsa Indonesia sebagaimana tersebut di atas (Sidharta, 2000) mengusulkan bahwa sistem/tatanan hukum 
nasional harus memuat ciri-ciri

sebagai berikut:

a. Berwawasan kebangsaan dan nusantara

b. Mampu

mengakomodir kesadaran hukum kelompok, etnis kedaerahan dan keyakinan keagamaan

c. Sejauh mungkin berbentuk tertulis dan terunifikasi

d. Bersifat rasional yang mencakup rasionaliatas efisiensi rasionalitas kewajaran (redeijkheid), rasionalitas kaidah dan rasionalitas kaidah

d. Aturan prosedural yang menjamin tranparansi yang memungkinkan kajian rasional terhadap pengambil keputusan oleh pemerintah

e. Responsif terhadap perkembangan aspirasi dan ekspektasi masyarakat (Sidharta, 2000).

Sehubungan dengan usulan di atas maka hasil seminar tentang hukum nasional di Fakultas Hukum Universitas Islam Indonesia
Yogyakarta yang dibukukan dengan judul "Identitas Hukum Nasional" merekomendasikan hukum Nasional yang sedang dibangun adalah:

a. Berlandaskan Pancasila (filosofis) dan UUD 1945 (konstitusional).

b. Berfungsi mengayomi, menciptakan ketertiban sosial, mendukung pelaksanaan pembangunan, dan mengamankan hasil-hasil dari pembangunan (Alkostar. 1997).

Dari uraian di atas maka dapat dikemukakan tujuan politik hukum Indonesia sebagaimana dikemukakan oleh Philippe Nonet dan Philip Selznick dalam bukunya "Law and Society in Transition: Toward Resposive Law" adalah menciptakan sistem hukum nasional yang rasional, transparan, demokratis, otonom, dan responsif terhadap perkembangan aspirasi dan ekspektasi masyarakat, bukan merupakan sistem hukum yang 
bersifat menindas, ortodoks, dan reduksionistik.

Untuk mewujudkan sistem hukum dimaksud maka sangat diperlukam kerja sama di antara berbagai pihak terutama pemerintah, partai politik dan masyarakat seperti halnya kompromi yang dilakukan dalam menetapkan Dasar Negara, tentang Sila Pertama yaitu "Ketuhanan dengan kewajiban menjalankan Syariat Islam bagi pemeluknya" dari Piagam Jakarta tanggal 22 Juni 1945 sebagai konsep Dasar Negara yang merupakan suatu proses konsep "politik hukum" baru bagi Negara Republik Indonesia, yang baru saja diproklamasikan pada tanggal 17 Agustus 1945 dengan UUD 1945 sebagai hukum dasarnya.

\section{Era Orde Baru}

Pada Era Orde Baru, telah disetujuinya Undang-undang Pengadilan Agama ini oleh Dewan Perwakilan Rakyat (DPR) RI, merupakan penegasan terhadap berlakunya hukum Islam yang semakin jelas ketika UU No. 7 Tahun 1989 tentang Peradilan Agama ditetapkan pada tanggal 29 Desember 1989, dan diundangkan dalam Lembaran Negara Nomor 49 tanggal 29 Desember 1989 oleh Sekretaris Negara, merupakan momentum yang penting dalam pembangunan sistem hukum nasional termasuk bagi umat Islam di Indonesia.25 Sebab hal ini semakin memantapkan kedudukan Pengadilan Agama sebagai salah satu badan pelaksana kekuasaan kehakiman yang mandiri di Indonesia dalam menegakkan hukum Islam bagi pencari keadilan sesuai hukum Islam bagi masyarakat Indonesia yang beragama Islam yang menyangkut perkara-perkara perdata di bidang perkawinan, kewarisan, wasiat, hibah, wakaf dan sedekah. Dengan demikian masyarakat Indonesia yang sebagian besar memeluk agama Islam memiliki kesempatan 
yang seluas-luasnya untuk menjalankan ketentuan hukum Islam yang menjadi ajaran agama sesuai ketentuan yang terkandung dalam pasal 29 ayat (2) UUD 1945.

\section{Era Reformasi}

Pada Era ini merupakan kebangkitan demokrasi dan kebebasan yang terjadi di seluruh pelosok tanah air Indonesia bersamaan dengan jatuhnya Soeharto penguasa Orde Baru selama kurang lebih 32 tahun. Setelah melalui perjalanan yang panjang, di era ini setidaknya hukum Islam mulai menempati posisinya secara perlahan tapi pasti. Lahirnya Ketetapan MPR No. III/MPR/2000 tentang Sumber Hukum dan Tata Urutan Peraturan Perundang-undangan, semakin membuka peluang lahirnya aturan undang-undang yang berlandaskan hukum Islam. Terutama pada Pasal 2 ayat 7 yang menegaskan ditampungnya peraturan daerah yang didasarkan pada kondisi khusus di suatu daerah di
Indonesia, dan peraturan tersebut dapat mengesampingkan berlakunya peraturan yang bersifat umum.

Lebih dari itu, disamping peluang yang semakin jelas, upaya kongkrit merealisasikan hukum Islam dalam wujud peraturan perundang-undangan telah membuahkan hasil yang nyata di era ini. Salah satu buktinya adalah terbitnya Undang-Undang Tentang Pemerintahan Daerah dan UndangUndang Otonomi Khusus serta Undang-Undang Daerah Istimewa. Seperti halnya Undang-Undang Nomor 32 Tahun 2004, tentang Pemerintahan Daerah, kemudian yang sangat menjadi perhatian adalah diterbitkannya UndangUndang No. 44 Tahun 1999 tentang Penyelenggaraan Keistimewaan Provinsi Daerah Istimewa Aceh dan Undang-Undang No. 18 Tahun 2001 tentang Otonomi Khusus Provinsi Daerah Istimewa Aceh sebagai Provinsi Nangroe Aceh Darussalam. Kedua produk hukum 
Pemerintah Provinsi Nangroe Aceh

Darussalam ini walaupun tidak berlaku secara nasional namun telah merubah hampir secara keseluruhan tatanan hukum dan politik di Aceh, bahkan ditengarai pula akan memberikan pengaruh yang tidak kecil terhadap pemerintah pusat (Syaukani \& Thohari, 2005).

Dalam penyelenggaraan Keistimewaan Provinsi Nangroe Aceh Darussalam terdapat empat keistimewaan yang dimiliki daerah ini sebagai berikut, (1) Penerapan syariat Islam dalam seluruh aspek kehidupan beragama, Penggunaan kurikulum pendidikan berdasarkan syariat tanpa mengabaikan kurikulum umum, (3) Pemasukan unsur adat dalam struktur Pemerintahan Desa dan, (4) Pengakuan peran Ulama dalam penetapan kebijakan daerah. Untuk menindaklanjuti undang-undang tentang Penyelenggaraan

Keistimewaan
Provinsi Daerah Istimewa Aceh tersebut maka Pemerintah Provinsi Nangroe Aceh Darussalam telah mengeluarkan empat Peraturan Daerah (Perda) atau Qanun. Adapun beberapa Qanun dimaksud masing-masing adalah, Qanun No. 3 Tahun 2000 tentang Organisasi dan Tata Kerja Majelis Permusyawaratan Ulama (MPU), Qanun No. 5 Tahun 2000 tentang Pelaksanaan Syariat Islam di Aceh, Qanun No. 6 Tahun 2000 tentang Penyelenggaraan Pendidikan dan Qanun No. 7 Tahun $2000 \quad$ tentang Penyelenggaraan Adat.

Berkaitan dengan isi beberapa Qanun tersebut maka pelaksanaan Syariat Islam sedemikian luasnya yang mencakup hukum tentang masalah ibadah, peradilan perdata dan pidana. Berkaitan dengan peradilan (qadha), pada tanggal 1 Muharram 1424 Hijriah bertepatan dengan tanggal 4 Maret 2003 melalui Keppres No. 11 Tahun 2003 
Pemerintah telah meresmikan berdirinya Mahkamah Syar'iyah, sehingga dapat melaksanakan syari'at Islam secara kaffah di wilayah Provinsi Nangroe Aceh Darussalam, dan Mahkamah Syar'iah ini nantinya akan menangani perkara-perkara perdata (ahwal al-syakhshiyyah) dan perkara pidana (jinayah), hal ini sesuai amanat Qanun No. 10 Tahun 2002, dan sesuai pula dengan Qanun Provinsi Nangroe Aceh Darussalam tentang Pelaksanaan Syari'at Islam Nomor 11 Tahun 2002.

Dengan demikian, di era reformasi ini, terbuka peluang yang luas bagi sistem hukum Islam untuk memperkaya khazanah tradisi hukum di Indonesia. Kita dapat melakukan langkah-langkah pembaruan, dan bahkan pembentukan hukum baru yang bersumber dan berlandaskan sistem hukum Islam, untuk kemudian dijadikan sebagai norma hukum positif yang berlaku dalam hukum Nasional kita.

\section{B. Pembinaan Hukum Nasional}

Menurut Ismatullah (2008), kata hukum Islam sama sekali tidak ditemukan dalam al-Quran dan literatur hukum dalam Islam, yang ada dalam al-Quran adalah kata syariah, fiqh, hukum Allah dan yang seakar dengannya. Atau yang biasa digunakan dalam literatur hukum dalam Islam adalah syari'at Islam, fiqh Islam dan hukum syara. Dengan demikian hukum Islam merupakan istilah khas Indonesia yang agaknya diterjemahkan secara harfiyah dari term Islamic Law dari literatur Barat. Jika demikian halnya, jelas istilah hukum Islam tidak merupakan terjemahan dari syari'ah, sebab Islamic Law sangat berbeda dengan syari'ah, baik filosofinya, sumber pengambilannya, tujuannya, dan sebagainya (Ismatullah, 2008).

Kedudukan hukum Islam dalam pembangunan hukum nasional melalui perjuangan yang 
cukup panjang dan baru mendapat titik terang setelah Pidato Menteri Kehakiman RI, Ali Said pada Upacara Pembukaan Simposium Pembaharuan Hukum Perdata Nasional di Yogyakarta pada tanggal 21 Desember 1981 yang menjelaskan bahwa disamping hukum adat dan hukum eks Barat, hukum Islam yang merupakan salah satu komponen tata hukum Indonesia, menjadi salah satu sumber bahan baku bagi pembentukan hukum nasional, kemudian kebijakan ini dijabarkan secara rinci delapan tahun kemudian (1989) oleh Menteri Kehakiman Ismail Saleh.

Namun sebelum mengetahui tempat hukum Islam dalam pembangunan hukum nasional terlebih dahulu kita mengikuti langkah-langkah kebijakan pembangunan hukum nasional melalui tiga dimensi antar lain, (1) Dimensi pemeliharaan yaitu memelihara tatanan hukum yang ada walaupun sudah tidak sesuai lagi dengan perkembangan masyarakat. Dimensi ini untuk menghindari kekosongan hukum hal ini sebagai konsekuensi logis dari Pasal II Aturan Peralihan UUD 1945, (2) Dimensi pembaharuan yaitu usaha untuk lebih meningkatkan dan menyempurnakan pembangunan hukum nasional, dimensi ini disamping pembentukan undangundang yang baru diusahakan pula penyempurnaan peraturan perundang-undangan yang ada sehingga sesuai dengan kebutuhan masa kini, (3) Dimensi penciptaan, yaitu dimensi dinamika dan kreativitas, dalam hal ini dimensi penciptaan perangkat perundang undangan yang baru, yang sebelumnya memang tidak pernah ada.

Hubungan hukum Islam dengan hukum nasional secara khusus tidak dapat dipungkiri bahwa penduduk Indonesia mayoritas memeluk agama Islam, menurut Menteri Kehakiman 
(Ismail Saleh) seyogyanya hukum Islam yang secara substansial terdiri dari dua bidang yaitu (1) bidang ibadah, dan (2) bidang muamalah. Artinya pengaturan hukum bertalian dalam bidang ibadah bersifat rinci sedangkan dalam bidang muamalah atau mengenai aneka kehidupan dalam masyarakat tidak bersifat rinci (Sidharta, 2000), artinya dalam bidang ini diatur hanya prinsipprinsipnya saja sedangkan aplikasinya dan pengembangannya diserahkan kepada penyelenggara negara/ pemerintah atau Ulil 'Amri.

Menurut Juhaya S. Praja, "teori kredo atau syahadat" yang mengharuskan pelaksanaan hukum Islam oleh mereka yang telah mengucapkan dua kalimat syahadat sesungguhnya kelanjutan dari prinsip tauhid dalam filsafat hukum Islam, yang menghendaki setiap orang yang menyatakan dirinya beriman kepada Allah Swt, maka ia harus tunduk kepada apa yang diperintahkan oleh Allah sekaligus taat kepada Rasullah Saw (Praja, 2011). Yang perlu menjadi perhatian bahwa karena hukum Islam memegang peranan yang penting dalam membina ketertiban sosial umat Islam dan mempengaruhi berbagai segi kehidupan maka yang harus ditempuh pemerintah adalah mengupayakan adanya transpormasi norma-norma hukum Islam kedalam hukum nasional sepanjang tidak bertentangan dengan Pancasila dan UUD 1945 (Menteri Kehakiman Ismail Saleh). Serta relevan dengan kebutuhan hukum khususnya umat Islam, karena cukup banyak asas-asas yang bersifat universal terkandung dalam hukum Islam yang dapat dipergunakan sebagai bahan/materi penyusunan hukum nasional.

Menurut Sayuti Thalib (1985), implementasi hukum Islam di Indonesia menggunakan teori receptie in complexy yang dirumuskan oleh Lodewijk Willem Cristian Van Den Berg (1845- 
1927) (Thalib, 1985). Sebelumnya teori ini juga disebutkan oleh H.A.R. Gibb, menurut teori ini bagi orang Islam berlaku penuh hukum Islam sebab dia telah memeluk Islam walaupun dalam pelaksanaannya masih terdapat penyimpangan-penyimpangan.

Secara fakta teori Berg lebih rinci dibandingkan teori yang dikemukakan H.A.R. Gibb, sebab prakteknya hingga sekarang umat Islam di Indonesia masih banyak yang belum taat dalam menjalankan ajaran Islam. Ketaatan mereka masih terbatas pada shalat lima waktu, zakat, puasa dan haji, sedangkan ajaran Islam lainnya masih kurang diperhatikan misalnya ajaran Islam tentang ekonomi dan perbankan Islam (Thalib, 1985).

Teori penerimaan hukum ini kemudian dikenal dengan istilah receptie in complex yaitu penerimaan hukum Islam secara keseluruhan oleh masyarakat yang beragama Islam. Karakteristik dari teori ini adalah hukum Islam dapat berlaku di Indonesia bagi pemeluk Islam, umat Islam harus taat pada ajaran Islam dan hukum Islam berlaku universal pada berbagai bidang ekonomi, hukum pidana dan hukum perdata (Praja, 2011).

\section{KESIMPULAN}

1. Pembangunan hukum Indonesia yang mayoritas Muslim harus memiliki kepedulian dan penuh keterbukaan tidak pelak lagi turut diwarnai oleh tuntutantuntutan umat Islam yang ingin menegakkan Syariat Islam. Gagasan ini tentu patut didukung. Namun sambil memberikan dukungan, perlu pula kiranya upaya-upaya semacam ini dijalankan secara cerdas dan bijaksana demi tercapai tujuan dan cita-cita besar bangsa ini. Karena menegakkan yang ma'ruf haruslah juga dengan menggunakan langkah yang ma'ruf. Disamping itu, kesadaran bahwa perjuangan penegakkan Syariat Islam sendiri adalah jalan yang panjang dan 
berliku, sesuai dengan sunnatullãh.

Karena itu dibutuhkan kesabaran dalam menjalankannya.

2. Model transformasi nilainilai syariat Islam dalam usaha politik Islam di Indonesia baru terimplementasikan di bidang moral (gerakan akhlak) belum tercapai dibidang legal hukum sejalan konsep pembentukan hukum Islam dengan prinsip bertahap (Tadarruj). Melalui proses pengakraban (harmonisasi) bangsa ini dengan hukum Islam yang selama ini telah dilakukan, harus terus dijalani dengan kesabaran dan kebijaksanaan. Disamping tentu saja upaya-upaya penguatan terhadap kekuatan dan daya tawar politis umat Islam perlu ditingkatkan.

3. Prospek legislasi syariat Islam di Indonesia tinggal penguatan mekanisme politiknya. Potensi besar umat Islam dari aktualisasi pelaksanaan normanorma syariat Islam dapat di kembangkan dalam kegiatan melalui payung hukum dengan berbagai perundang-undangan di Indonesia, peraturan-peraturan daerah yang sejalan dengan normanorma syariat Islam mengandung esensi keadilan, kemaslahatan dan kesejahteraan. 


\section{DAFTAR PUSTAKA}

Ali, M. D. (2013) Hukum Islam (Pengantar Ilmu Hukum dan Tata Hukum Islam di Indonesia, Jakarta: PT. Raja Grfindo Persada.

Ash-Shiddiqy, M. H. (1993). Falsafah Hukum Islam. Jakarta: Bulan Bintang.

Alkostar, A. (1997). Identitas Hukum Nasional, Yogyakarta: Fakultas Hukum UII.

Cahyadi, A. \& Manulang, E. F. M. (2007). Pengantar ke Filsafat Hukum. Jakarta: Kencana Prenada Media Group.

Isjwara, F. (1964). Pengantar Ilmu Politik. Bandung : Dhiwantara.

Ismatullah, D. (2008) Sejarah Sosial Hukum Islam. Bandung:Tsabita.

Khallaf, A. W. (2005). Politik Hukum Islam, alih bahasa Zainudin Adnan, cet. ke-2. Yogyakarta: Tiata Wacana.

Moh. Mahfud MD. (2010). Politik Hukum di Indonesia, Jakarta: PT.Rajawali Persada.

Praja, j. S. (2011). Teori Hukum dan Aplikasinya. Bandung: CV Pustaka Setia.

Rahardjo, S. (1988). Pembangunan Hukum Nasional Dan Perubahan Sosial, Bandung: Angkasa.

Syaukani, I \& Thohari, A. A. (2005) Dasar-Dasar Politik Hukum, Jakarta: PT. Raja Grafindo Persada.

Sidharta, A. (2000) Refleksi Tentang Struktur Ilmu Hukum, Sebuah Penelitian tentang Fondasi Kefilsafatan dan Sifat Keilmuan Ilmu Hulum Sebagai Landasan Pembangunan Ilmu Hukum Nasional Indonesia. Bandung: Mandar Maju. 
Thalib, S. (1985). Receptie A Contratrio, Hubungan Hukum Adat dan Hukum Islam. Jakarta: Bina Aksara.

UUD 1945, Undang-Undang Konstitusi RIS 1949, UUDS 1950, UUD 1945 yang diamandemen.

Wahyono, P. (1986). Kerangka Pembangunan Hukum di Indonesia. Jakarta: Pustaka Sinar Harapan.

Wibawa, S. (2001). Negara-Negara di Nusantara (Dari Negara Kota Hingga Negara Bangsa dari Modernisasi Hingga Negara Bangsa dari Modernisasi Hingga Reformasi Administrasi), Yogyakarta: Gajah Mada University Press. 